\title{
Feasibility Analysis of Radec Learning Designs to Build Students'collaboration Skills In Determining pH Routes From Natural Indicators
}

\author{
Dini Intania Sari", Wawan Wahyu ${ }^{2}$, Wahyu Sopandi ${ }^{3}$ \\ ${ }^{1}$ State Senior High Schools 2 Ujungbatu, Rokan Hulu, 28554, Indonesia \\ ${ }^{2}$ Chemical Education Postgraduate Students, Indonesia University of Education, Bandung, 40154, Indonesia
}

\section{ARTICLE INFO}

\section{Article history:}

Received: 09 Aug 2021

Revised: 13 Jan 2022

Accepted: 14 Jan 2022

Published online: 24 Jan 2022

Keywords:

Learning Design

Collaboration Skills

RADEC Model

\begin{abstract}
A B S T R A C T
Student collaboration skills are one of the important things that can support 21st Century Skills. The purpose of this study is to develop students' collaboration skills in learning natural acid-base indicators using the appropriate learning model RADEC (Read, Answer, Discuss, Explain, Create). The research method used in this research is descriptive evaluative. This study involved 2 experts and 3 senior teachers to test the feasibility. A limited trial was given to 25 students from one of the State Senior High Schools (SMAN) in Rokan Hulu Regency, Riau Province. The instrument used is an internal due diligence sheet, an external feasibility test sheet, and an observation sheet on student collaboration skills. Data from the results of the feasibility test were scored, presented, tabulated, and categorized. Data from the results of observations and assessment reports are described and categorized. The results showed that the model RADEC was declared feasible based on internal, external, and feasibility tests TCOF. Students' collaboration skills are categorized as very good after learning through the model RADEC.
\end{abstract}

\section{Introduction}

The development of the 21st century brings a great impact in various life and education sciences. The 21 st century is marked by the development of science, technology, and the availability of a lot of information and the rapid development of computing is a challenge in itself. The 21 st century is a century of world unification in global challenges full of openness (Wijaya et al., 2016). This is also a challenge for the education system to be able to prepare competitive quality human resources (HR) in the global era. In the 21 st century a person is required to have the skills to think, communicate, and collaborate in order to work together in a team, this has increased due to the use of technology and machines to meet the 
needs of life and human resources that are routine from year to year (Care et al., 2015); (Spektor-Levy et al., 2008). Thus improving the quality of education becomes a necessity to address the problems faced by students.

Learning and innovation skills are needed to prepare students to cope with an increasingly complex life. There are four competencies that must be owned the students for the challenges of the 21 st century is known as the " $21^{\text {st }}$ Century Skills" or skills of the $21 \mathrm{st}$ century, namely: (1) the skills to create and update(Creativity), (2) critical thinking skills, (3)skills (communication), and (4) work together (collaboration) (Kay \& Greenhill, 2011). All 21st century competencies must be obtained by students through education, so that students are able to compete and survive in this modern era.

The educational process today tends to increasingly ignore elements of "educating" and education as if replaced by activities that emphasize more on aspects that are "problem-working" in order to pursue curriculum targets alone. The learning atmosphere is characterized by the existence of competition among students and has neglected the principle of meaningful learning which is more functional and contextual. Students are required to be able to compete to be the best in school so that they try to learn from various sources. The learning method that only transmits knowledge, by Hiltz in (Ramdani et al., 2019) said as, the sage on the stage, does not provide opportunities for students to interact and transact between students causing them to lose their time to articulate learning experiences. Learning that provides training in critical thinking and social interaction only gets a very small portion of time because educators are only busy with routine tasks to immediately complete the curriculum which is their responsibility (Setyosari, 2019).

One of the provisions for dealing with these problems is with collaborative skills. The importance of having these skills is so that humans are able to socialize, be sensitive to the surrounding environment, and control ego and emotions. Collaboration skills are the ability to participate in every activity to foster relationships with others, respect mutual relationships and teamwork to achieve the same goal (Hinyard et al., 2019). Indicators that show collaboration skills are contributing actively, working productively, showing flexibility and compromise, showing responsibility, and showing respect (Redhana, 2019).

One way to practice collaboration skills is through education (Istiyono et al., 2014). Education that is not only carried out to develop knowledge based on the core subject of learning, but must also be oriented so that students have collaborative abilities (Ramdani et al., 2019). So that students have these abilities, they can train them by giving challenging problems that exist in real life (Zubaidah, 2019). Learning efforts should be more directing students so that they have a harmonious life, namely living together with others, respecting each other's opinions, respecting people speaking, responsibility, willing to sacrifice, accommodating, and have a big spirit (Leopold \& Smith, 2020). Methods that are considered capable of driving a learning process like this are through collaborative learning. It needs to be realized that since birth humans live in a 
family environment, peer groups, school communities, nations, and even communities between nations or the world (Neiles et al., 2019).

The curriculum applied in Indonesia today is the 2013 Curriculum, which is designed to develop a balance between the development of spiritual and social attitudes, curiosity, creativity, and collaboration with intellectual and psychomotor abilities. This curriculum was also supported by Regulation of the Minister of Education and Culture of the Republic of Indonesia No. 81 A of 2013 concerning the Implementation of the 2013 Curriculum. One of the implementations is to develop creativity by considering the moral and values of Pancasila and live in a society.

The success of increasing students' collaboration skills is also affected by the ability of a teacher to design learning. Despite having adequate educational qualifications, Law No. 14 of 2015 confirms that professional teachers have four basic professional competencies: pedagogical competence, personality competence, professional competence, and social competence. Pedagogical competence, in this case, is the ability to manage the learning of students. In order for students to have the ability to collaborate, the teacher must be able to train them by using appropriate strategies in learning activities, for example by carrying out practical activities during the implementation of learning. Students can be said to have the ability to collaborate, so they must fulfill 3 components of the ability to collaborate, namely: a) Demonstrate the ability to work effectively and respect the diversity of the team; b) Demonstrate flexibility and willingness to accept the opinions of others in achieving common goals. c) Take joint responsibility in collaborative work and appreciate the contribution of each team member (Trilling \& Fadel, 2009).

Various innovative learning models have actually been applied to meet the challenges of the 21st century in improving the collaboration skills and creativity of students in Indonesia. In general, the learning models that are widely used by teachers are learning models adopted from abroad, such as Project-based Learning (PjBL), Problem-based Learning $(P B L)$, Inquiry, and others. However, this learning model cannot be implemented optimally by teachers in Indonesia due to several obstacles. The obstacle experienced in the field is that teachers have difficulty in implementing it because they do not understand the stages of learning which result in a lot of time being used (Alves et al., 2012); (Woro Sumarni., 2015). In addition to the application of this model, teachers often focus on projects that must be completed by students, this causes a lack of time allocation for the study of concepts or materials that should be understood in depth by students (Grant, 2002). In practice, teachers often experience obstacles to implementing innovative learning models that come from abroad because the conditions of education abroad are not the same as the conditions of education in Indonesia (Pratama et al., 2019).

Sopandi (2019) emphasized the need for alternative solutions to overcome the problems of teachers in Indonesia by developing an appropriate learning model. Therefore, we need an alternative learning model in accordance with the context 
of education in Indonesia. Another alternative model offered in this study is the learning model $R A D E C$. This model becomes a new alternative learning model that aims to help students gain many useful competencies (Sopandi, 2017). In contrast to other learning models that have emerged from abroad, this model appears in relation to juridical, philosophical, factual, and theoretical contexts that are appropriate to the Indonesian context (Sopandi, 2017). Based on the results of the socialization activities and workshops attended by 92 participants (elementary, middle, and high school teachers), information was obtained that all participants stated that the learning model was $R A D E C$ easy to understand because it had easy-to-remember learning stages (Sopandi, 2019). Other results show that the learning model $R A D E C$ can also be a solution to the demands of the 21 st century and can be another alternative solution to innovative learning models created from abroad.

The advantages of the model $R A D E C$ in learning include: 1) At the stage read and answer students are asked to carry out reading activities outside the classroom before learning begins, and answer questions pre-learning in the LKPD so that students have initial knowledge before learning begins; 2) at the discuss and explain stage, namely the stage of instilling the concept. Learners are trained to build their own knowledge before discussing it in groups and classes. Students are trained to express their ideas and ideas while constructing their own knowledge. At this stage students try to solve the problems given by using the concepts they have obtained previously in the stages read and answer; 3) at the stage, create students are given the opportunity to be creative in solving problems given through practical activities. The stages discuss, explain and create provide a huge opportunity to develop collaboration and creativity skills in learning activities.

Research using the model RADEC has been widely carried out and published, both researched at UPI and outside UPI, both national and international journals, including Agustin et al. (2021) which states that the RADEC learning model has a more significant positive effect on increasing students' HOTS in advanced elementary science subjects compared to inquiry learning; Anggraeni et al. (2021) showed that the critical thinking skills of PGSD students on reproductive materials in plants through inquiry-oriented RADEC learning had sufficient categories; Handayani et al. (2019) shows that the RADEC learning model has a good impact on the ability of prospective teachers to plan lessons; Maruf et al. (2020)showed that learning design using the model RADEC with aapproach is STEM -based Google Classroom feasible to use to increase student creativity; Putra et al. (2018) resulted in one solution to be able to build critical thinking skills using the RADEC learning model; Rahman et al. (2020) stated that RADEC can be an alternative teaching method during this pandemic which hinders the direct teaching and learning process; Rohmawatiningsih et al. (2021) stated that the application of the RADEC learning model can improve students' conceptual understanding of electrical phenomena. ; Handayani et al. (2019) stated that the RADEC model makes all students have the capacity to learn independently and learn better. From the research that has been carried out, it shows positive results, including an increase in students' creativity, an increase in critical thinking skills, 
the ability to write explanatory texts, the ability to design lessons for teachers and a fondness for reading teaching materials.

Research related to the learning model $R A D E C$ to build collaboration skills and creativity of students has yet to be found, especially in chemistry subjects on the indicator material for determining the $\mathrm{pH}$ trajectory of natural natural indicators. Based on KD 4.8, namely regarding the analysis of the $\mathrm{pH}$ route of several indicators extracted from natural materials through experiments, students are required to determine the $\mathrm{pH}$ route of natural indicators derived from natural materials available in the surrounding environment, so that students can build collaboration skills and creativity in choose materials that can be used as natural indicators that they will determine the $\mathrm{pH}$ trajectory. The results of research conducted by Laub (1999); Sharma et al. (2016) it is known that natural indicators derived from natural ingredients produce colors and extracts are recommended to be used as alternative indicators in the titration process to determine the $\mathrm{pH}$ trajectory of natural indicators. Natural indicators have the characteristics of being widely available in nature, cheap and environmentally friendly. It can be said that, the product resulting from this research has benefits. Based on the background stated, the researchers feel it is very important to conduct research that aims to prepare students to face challenges in the $21 \mathrm{st}$ century by having collaboration skills through learning designs for determining the $\mathrm{pH}$ trajectory of natural indicators using the model $R A D E C$.

\section{Methodology}

The methodology used in this study was descriptive research. Descriptive research is defined as research that does not aim at examining hypotheses, but only explains the actual state of variables in the field (Arikunto, 2010). According to Noor (2011), descriptive research has specific steps in its implementation, namely: beginning with a problem, determining the type of information needed, determining data collection procedures, determining information processing procedures or data and drawing research conclusions.

The study involved some participants in answering research questions. The feasibility test of the design of the $\mathrm{pH}$ trajectory analysis of natural indicators learning involved two experts and one senior teacher for the internal feasibility test. Three Class XI high school students whose locations were close together (due to being in a pandemic corona outbreak condition) were involved for an external feasibility test. Eligibility criteria were assessed using eligibility criteria according to (Wiersma \& Jurs, 2009), which were then processed into scores and interpreted using score interpretations, according to (Riduwan., 2015). The instrument used in this study was the feasibility test of earning design that would obtain data on the suitability of the collaboration sub-indicator with learning activities. The collaborative instrument developed in this study refers to the Standard Rubric of the International Reading Association (IRA). In the standard rubric, aspects that include the ability to collaborate are contributions, time management, problem solving, working with others, investigation techniques and 
synthesis (ReadWriteThink, 2005). The technique of collecting data on the implementation of the learning model design implementation test was carried out by means of a self-assessment (collaborative assessment questionnaire) filled out by students.

\section{Research Instruments}

The instrument used is a non-test instrument in the form of student activity observation sheets during the learning process which consists of five indicators of student activity, namely contributions, time management, problem solving, working with others and investigative techniques. Each indicator has criteria that are used as tasks to assess collaboration skills. Analysis of the results of observations is done by determining the percentage score for each indicator of collaboration skills at each stage of RADEC.

\section{Results and Discussion}

Analysis of the feasibility of the RADEC model learning design on $\mathrm{pH}$ trajectory analysis material from natural indicators using google classroom and zoom media because during the Covid-19 pandemic where learning takes place online by following the RADEC syntax (Read, Answer, Explain and Create). The findings obtained from each stage in the RADEC learning model can be seen in Table 2.

Table 2. Conformity between the Collaboration Skills Sub-Indicators and Learning Activities

\begin{tabular}{|c|c|c|c|c|}
\hline No. & $\begin{array}{c}\text { RADEC } \\
\text { Learning } \\
\text { Model } \\
\text { Stage }\end{array}$ & Learning Activities & $\begin{array}{c}\text { Collaborative Skills Sub } \\
\text { Indicator }\end{array}$ & $\begin{array}{c}\% \\
\text { Conformity }\end{array}$ \\
\hline \multirow[t]{3}{*}{1} & Read & $\begin{array}{l}\text { Students mark the } \\
\text { problems found in the }\end{array}$ & $\begin{array}{lll}\begin{array}{l}\text { Participate } \\
\text { activities }\end{array} & \text { in } & \text { learning } \\
\end{array}$ & 100 \\
\hline & & material for determining & Do the job well and on time & 95 \\
\hline & & $\begin{array}{l}\text { the route of the natural } \\
\text { acid-base } \mathrm{pH} \text { indicator. }\end{array}$ & Participate in finding problems & 95 \\
\hline \multirow[t]{3}{*}{2} & Answer & $\begin{array}{l}\text { Students answer pre- } \\
\text { learning questions on }\end{array}$ & $\begin{array}{l}\text { Give input / opinion in the } \\
\text { group }\end{array}$ & 95 \\
\hline & & LKS & Make efforts to solve problems & 95 \\
\hline & & & $\begin{array}{l}\text { Listen and respect the opinions } \\
\text { of others }\end{array}$ & 100 \\
\hline \multirow[t]{5}{*}{3} & Discuss & $\begin{array}{ll}\text { Learners } & \text { can } \\
\text { communicate } & \text { and }\end{array}$ & $\begin{array}{l}\text { Give input / opinion in the } \\
\text { group }\end{array}$ & 95 \\
\hline & & $\begin{array}{l}\text { collaborate with their } \\
\text { group mates regarding }\end{array}$ & $\begin{array}{l}\text { Carry out assigned } \\
\text { responsibilities on time }\end{array}$ & 100 \\
\hline & & $\begin{array}{l}\text { the answers obtained in } \\
\text { pre-learning questions }\end{array}$ & $\begin{array}{l}\text { Provide ideas to answer } \\
\text { problems }\end{array}$ & 95 \\
\hline & & $\begin{array}{l}\text { and the problems } \\
\text { obtained in the natural }\end{array}$ & $\begin{array}{l}\text { Listen and respect the opinions } \\
\text { of others }\end{array}$ & 95 \\
\hline & & $\begin{array}{l}\text { acid-base indicator } \\
\text { material. }\end{array}$ & $\begin{array}{l}\text { Report the results of the } \\
\text { investigation }\end{array}$ & 95 \\
\hline 4 & Explain & $\begin{array}{l}\text { The teacher gives an } \\
\text { opportunity for the group }\end{array}$ & $\begin{array}{l}\text { Giving input/opinion in class } \\
\text { discussion }\end{array}$ & 95 \\
\hline
\end{tabular}




\begin{tabular}{|c|c|c|c|c|}
\hline \multirow{9}{*}{5} & \multirow{9}{*}{ Create } & \multirow{4}{*}{$\begin{array}{l}\text { to appear communicating } \\
\text { the results of the } \\
\text { discussion, both answers } \\
\text { for pre-learning and } \\
\text { problems found in the } \\
\text { zoom application }\end{array}$} & $\begin{array}{l}\text { Collect assigned tasks properly } \\
\text { and on time }\end{array}$ & 95 \\
\hline & & & $\begin{array}{l}\text { Listen and respect the opinions } \\
\text { of others }\end{array}$ & 100 \\
\hline & & & $\begin{array}{l}\text { Record the information } \\
\text { obtained }\end{array}$ & 95 \\
\hline & & & $\begin{array}{l}\text { Report the results of the } \\
\text { investigation }\end{array}$ & 90 \\
\hline & & \multirow{4}{*}{$\begin{array}{l}\text { 1. Each group discusses to } \\
\text { determine the project } \\
\text { that will be made in the } \\
\text { manufacture of natural- } \\
\text { based indicators, and } \\
\text { fills in the 1st part of } \\
\text { the LKS (project design } \\
\text { stage) }\end{array}$} & $\begin{array}{l}\text { Give input / opinion in the } \\
\text { group }\end{array}$ & 95 \\
\hline & & & Arrive on time & 95 \\
\hline & & & $\begin{array}{l}\text { Creating a friendly atmosphere } \\
\text { of cooperation }\end{array}$ & 95 \\
\hline & & & Want to help others & 100 \\
\hline & & $\begin{array}{l}\text { 2. Each group makes } \\
\text { natural-based indicators } \\
\text { from selected natural } \\
\text { materials } \\
\text { determines the pH } \\
\text { trajectory of the } \\
\text { indicator. }\end{array}$ & & \\
\hline
\end{tabular}

Based on Table 2. the percentage of the average score of the student collaboration skills indicator at each stage of RADEC shows that the Read stage has a score of 96.67\%, Answer has a score of 99\%, Discuss has a score of $98.33 \%$, Explain gets a score of $95 \%$, and for create has a score of $96.67 \%$. Of all the learning stages, the explain stage has the lowest score percentage. The findings during the research regarding the collaboration skills of students through natural indicator learning design using the RADEC model are described according to the stages of the RADEC model as follows:

\section{Read}

The internal feasibility test at this stage has a score percentage of $96.67 \%$ and falls into the very strong category and is the smallest result obtained from each stage. Learning activities carried out by students are reading and looking for various sources of information to understand acid-base indicator material. This learning activity is carried out by students outside the classroom before learning begins. Each student is asked to read and understand the subject matter. At the read stage, the expected sub-indicator of collaboration skills is that students participate in learning activities, do assignments well and on time and participate in finding problems. In this stage, all examiners gave a score of $95 \%$. This shows that the research design made by the researcher lacks collaboration skills in the reading stage.

\section{Answer}

In the Answer stage, the total score obtained is $98.33 \%$ which is categorized as very strong. At this stage, students' learning activities are to answer pre-learning 
questions in the LKS and explain the problems they encounter after doing Read. This activity can build students' collaboration skills in completing the assigned tasks. The sub-indicators of collaboration skills that appear at this stage are providing input/opinions in groups that score $100 \%$, making efforts to solve problems $95 \%$ and listening and respecting other people's opinions with a score of $100 \%$.

\section{Discuss}

Discuss stages get the highest score from all learning stages, which is $100 \%$ with a very strong category. At this stage, all indicators of collaboration skills are raised, namely contributions, time management, problem solving, collaborating with others and investigative techniques. At the discuss stage, students are expected to be able to communicate and work together with their group friends to discuss pre-learning questions in the LKS and other problems they get on acidbase indicator material. The sub-indicators of skills that appear at this stage are providing input/opinions in the group, working on the assigned responsibilities on time, giving ideas for answering problems, listening and respecting the opinions of others and reporting the results of the investigation.

\section{Explain}

After discussing in groups, students do presentation activities. At this stage the score obtained is $95 \%$ which is categorized as very good. Even though the explain stage was categorized as very good, it got the lowest score from the other learning stages. The sub-indicators of collaboration skills that appear at this stage are providing input/opinions in class discussions with a score of $100 \%$, collecting assignments given properly and on time $95 \%$, listening to other people's opinions $95 \%$, recording information obtained $95 \%$ and reported $90 \%$ investigation results. The lowest score at this stage is the sub-indicator reporting the results of the investigation. Of the 5 examiners, 2 of them gave a score of 3 . This is because in the research design the researchers did not provide clear information in the technique of reporting the results of the investigation. Techniques for reporting the results of the investigation can be orally or in writing. In the explain stage, the student's activity is to do presentation activities. In the research design, researchers should explain in more detail about the implementation of this stage so that learning activities run well.

At the explain stage, the teacher gives an opportunity for each group to present the results of the discussions they have done in answering pre-learning questions in the LKS. Materials that will be presented in the form of presentations include indicators of cognitive aspects of learning that have been formulated in the design of learning implementation. At this stage, each group appoints a representative of its members who are considered capable of explaining the material to be presented for presentation. Explaining activities are carried out through zoom media because learning is done online (online). The use of zoom in learning proves the need for mastery of teachers and students in utilizing information and communication technology (ICT) in learning. This indicates the orientation of the RADEC model. 


\section{Create}

In the create stage, each group discusses to determine the project to be made in the manufacture of natural-based indicators, and fills in the 1st part of the LKS (project planning stage). Each group was asked to make an indicator made from natural ingredients selected and determine the $\mathrm{pH}$ trajectory of the indicator. The sub-indicators that appear in this stage are providing input/opinion in the group $(95 \%)$, arriving on time $(95 \%)$, creating a friendly atmosphere of cooperation $(100 \%)$ and being willing to help others (100\%). In all stages of the RADEC model, the overall score obtained from the suitability between the sub-indicators of collaboration skills with learning activities is $97.3 \%$ which is categorized as very strong, this shows that the design of learning acid-base indicators using the RADEC model is feasible to use to build collaboration skills. learners.

\section{Conclusion}

Based on the results of the analysis and discussion, it can be concluded that the learning design for determining the $\mathrm{pH}$ trajectory of natural indicators using the RADEC model based on Google classroom is suitable for developing students' collaboration skills. The suitability of this learning design can be seen from the overall average score of each stage of the RADEC Model which is categorized as very feasible for developing student collaboration skills.

\section{Acknowledgement}

Thanks to Mr. Dr. Wawan Wahyu, M.Pd., Mr. Prof. Dr.paed Wahyu Sopandi, M.A., who has provided guidance for this research. The author would also like to thank the chemistry teacher, observer, as well as the XI.1 class students who have helped the researcher in conducting the research.

\section{References}

Agustin, M., Pratama, Y. A., Sopandi, W., \& Rosidah, I. (2021). Pengaruh Model Pembelajaran Radec Terhadap Keterampilan Berpikir Tingkat Tinggi Mahasiswa PGSD. Jurnal Cakrawala Pendas.

Alves, A. C., Mesquita, D., Moreira, F., \& Fernandes, S. (2012). Teamwork in Project-Based Learning: perceptions of strengths and weaknesses 1 Introduction 2 Context of the Study. Proceedings of the Fourth International Symposium on Project Approaches in Engineering Education (PAEE'2012).

Anggraeni, P., Sopandi, W., Septinaningrum, S., Hayati, A., Tursinawati, T., \& Yosi Gumala, Y. G. (2021). Keterampilan Berpikir Kritis Mahasiswa PGSD Melalui Pembelajaran Read-Answer-Discuss-Explain-And Create (RADEC) yang Berorientasi Penyelidikan. Caruban: Jurnal Ilmiah Ilmu Pendidikan Dasar. 
Arikunto, S. (2010). Prosedur penelitian. PT Rineka.

Care, E., Griffi, P., Scoular, C., Awwal, N., \& Zoanetti, N. (2015). Assessment and Teaching of 21st Century Skills. Assessment and Teaching of 21st Century Skills, 85-104.

Grant, M. (2002). Getting a grip on project-based learning: theory, cases, and recommendations. Meridian: A Middle School Computer Technologies Journal, 5 (1). Journal of Research on Technology in Education.

Handayani, H., Sopandi, W., Syaodih, E., Setiawan, D., \& Suhendra, I. (2019). Dampak Perlakuan Model Pembelajaran Radec Bagi Calon Guru Terhadap Kemampuan Merencanakan Pembelajaran di Sekolah Dasar. Pendas: Jurnal Ilmiah Pendidikan Dasar.

Hinyard, L., Toomey, E., Eliot, K., \& Breitbach, A. (2019). Student Perceptions of Collaboration Skills in an Interprofessional Context: Development and Initial Validation of the Self-Assessed Collaboration Skills Instrument. Evaluation and the Health Professions.

Istiyono, E., Mardapi, D., \& Suparno, S. (2014). Pengembangan Tes Kemampuan Berpikir Tingkat Tinggi Fisika (Pysthots) Peserta Didik SMA. Jurnal Penelitian Dan Evaluasi Pendidikan, 18(1), 1-12.

Kay, K., \& Greenhill, V. (2011). Twenty-First Century Students Need 21st Century Skills. In Bringing Schools into the 21st Century.

Laub, J. A. (1999). Assessing the servant organization; Development of the Organizational Leadership Assessment (OLA) model. Dissertation Abstracts International,. Procedia - Social and Behavioral Sciences.

Leopold, H., \& Smith, A. (2020). Implementing reflective group work activities in a large chemistry lab to support collaborative learning. Education Sciences.

Maruf, A. S., Wahyu, W., \& Sopandi, W. (2020). Colloidal Learning Design using Radec Model with Stem Approach Based Google Classroom to Develop Student Creativity. Journal of Educational Sciences.

Neiles, K. Y., Bowers, G. M., Chase, D. T., Vermeulen, A., Hovland, D. E., Bresslour-Rashap, E., Eller, L., \& Koch, A. S. (2019). Teaching Collaborations and Scientific Practices through a Vertically Scaffolded Biodiesel Laboratory Experience. Journal of Chemical Education.

Noor, J. (2011). Metodologi Penelitian: Skripsi, Tesis, Disertasi, \& Karya Ilmiah. Metodologi Penelitian: Skripsi, Tesis, Disertasi, \& Karya Ilmiah.

Pratama, Y. A., Sopandi, W., \& Hidayah, Y. (2019). Model Pembelajaran Radec (Read-Answer-Discuss-Explain And Create): Pentingnya Membangun Keterampilan Berpikir Kritis Dalam Konteks Keindonesiaan. Indonesian Journal of Learning Education and Counseling.

Putra, M. J. A., Widodo, A., \& Sopandi, W. (2018). Content Representation on Earth and Space Topic by Experienced and Prospective Primary Teachers.

Rahman, A., Suherman, A., Susilawati, D., \& Putra, G. P. (2020). RADEC (reading, answering, demonstrating, explaining, and creating) in $1 \mathrm{~ms}$ to teach tennis without field practicing. Universal Journal of Educational Research.

Ramdani, Z., Amrullah, S., \& Tae, L. F. (2019). Pentingnya Kolaborasi dalam Menciptakan Sistem Pendidikan yang Berkualitas. Mediapsi, 5(1), 40-48.

ReadWriteThink. (2005). Collaborative Work Skills Rubric. International 
Reading Association/Ncte., 2015. www.learningsciences.com

Redhana, I. W. (2019). Mengembangkan Keterampilan Abad Ke-21 Dalam Pembelajaran Kimia. Jurnal Inovasi Pendidikan Kimia, 13(1).

Riduwan. (2015). Skala Pengukuran Variabel-Variabel Penelitian. Alfabeta.

Rohmawatiningsih, W., Rachman, I., \& Yayoi, K. (2021). The implementation of RADEC learning model in thematic learning to increase the concept understanding of electrical phenomenon. Momentum: Physics Education Journal.

Setyosari, P. (2019). Pembelajaran Kolaborasi Landasan untuk mengembangkan keterampilan sosial, rasa saling menghargai dan tanggung jawab - Prof. Dr. Punaji Setyosari 2009.pdf.

Sharma, P., Gupta, R., Roshan, S., Sahu, S., Tantuway, S., Shukla, A., \& Garg, A. (2016). Plant extracts as acid base indicator: an Plant Extracts as Acid Base Indicator: An Overview. In inventi.

Sopandi, W. (2017). The quality improvement of learning processes and achievements through the read-answer-discuss-explain-and create learning model implementation. Proceeding 8th Pedagogy International Seminar 2017: Enhancement of Pedagogy in Cultural Diversity Toward Excellence in Education.

Sopandi, W. (2019). Sosialisasi dan Workshop Implementasi Model Pembelajaran RADEC Bagi Guru-Guru Pendidikan Dasar dan Menengah [Dissemination and Implementation Workshop of RADEC Learning Models for Primary and Secondary Education Teachers]. PEDAGOGIA: Jurnal Pendidikan, $8(1), 19$.

Spektor-Levy, O., Eylon, B. S., \& Scherz, Z. (2008). Teaching communication skills in science: Tracing teacher change. Teaching and Teacher Education, 24(2), 462-477.

Sumarni, W. (2015). The strengths and weaknesses of the implementation of project based learning: A review. International Journal of Science and Research, 4(3), 478-484.

Trilling, B., \& Fadel, C. (2009). Learning Past and Future. In 21st century skills : learning for life in our times.

Wiersma, W., \& Jurs, S. G. (2009). Research Methods in Education an Introduction. : Pearson Education, Inc.

Wijaya, E. Y., Sudjimat, D. A., \& Nyoto, A. (2016). Transformasi pendidikan abad 21 sebagai tuntutan pengembangan sumber daya manusia di era global. Prosiding Seminar Nasional Pendidikan Matematika 2016.

Zubaidah, S. (2019). Keterampilan Abad Ke-21: Keterampilan Yang Diajarkan Melalui Pembelajaran. Seminar Nasional Pendidikan Dengan Tema "IsuIsu Strategis Pembelajaran MIPA Abad 21, Desember, 1-17.

How to cite this article:

Sari, D. I., Wahyu, W., \& Sopandi, W. (2022). Feasibility Analysis of Radec Learning Designs to Build Students'collaboration Skills In Determining $\mathrm{pH}$ Routes From Natural Indicators. Journal of Educational Sciences, 6(1), 35-45. 